Article

\title{
Supply Chain-Based Business Model Innovation: The Case of a Cross-Border E-Commerce Company
}

\author{
Ying Wang ${ }^{1}$, Fu Jia ${ }^{1, *}$, , Tobias Schoenherr $^{2}$ and Yu Gong ${ }^{3}(\mathbb{D}$ \\ 1 School of Economics and Management, Minjiang University, Fuzhou 350108, China; wang@mju.edu.cn \\ 2 Broad College of Business, Michigan State University, East Lansing, MI 48824, USA; \\ schoenherr@broad.msu.edu \\ 3 Southampton Business School, University of Southampton, Southampton SO17 1BJ, UK; y.gong@soton.ac.uk \\ * Correspondence: fu.jia@exeter.ac.uk
}

Received: 1 October 2018; Accepted: 11 November 2018; Published: 23 November 2018

check for updates

\begin{abstract}
Cross-border e-commerce has gained increasing popularity globally and thrives under the backdrop of the 'One Belt One Road' policy of China, which resonates with UN's sustainable development goals targeting countries in the South. In this study, we investigate Zongteng, which is one of the first cross-border e-commerce companies in China, to assess how supply chain innovation activities can become core to a firm's business model innovation. Data were collected from Zongteng senior managers, internal company documents, and open online resources. We found that the firm needed changes in its business model, which brought new participants into the business ecosystem and changed their respective positions. We further identified three types of supply chain localisations in cross-border e-commerce for export markets (sales, warehousing, and R\&D localisation), which the company's establishment of overseas warehouses enabled. The three localisation strategies serve as the driving force and the main business model innovation in cross-border e-commerce. This study contributes to the supply chain innovation literature by proposing that overseas warehouses, bonded warehouses, and supply chain finance are capabilities that form part of the business model innovation in cross-border e-commerce.
\end{abstract}

Keywords: supply chain innovation; business model innovation; cross-border e-commerce; business ecosystem

\section{Introduction}

With the popularisation of the Internet and the advancement of information technology, e-commerce has prospered in the global context. As such, an increasing number of companies conduct business via the Internet and more consumers shop online. The World Trade Organization (2013) [1] (p. 1) defines e-commerce as the sale or purchase of goods or services through computer networks with methods specially designed to place and receive orders. Furthermore, cross-border e-commerce represents different transactions through an e-commerce platform to complete transactions, payments, and settlements, and through cross-border logistics services to complete international business transactions [2]. Although cross-border e-commerce has many characteristics of domestic e-commerce [3], the main difference is that merchants and customers can sell or purchase goods or services via the Internet from anywhere worldwide, which makes cross-border e-commerce more complex than domestic e-commerce.

The rapid development of cross-border e-commerce in China is under the backdrop of The Silk Road Economic Belt and the 21st Century Maritime Silk Road-better known by its popular shorthand terms of One Belt, One Road (OBOR), or the Belt-Road initiative, which has become one of the most discussed topics about China's evolving role in the global economy today [4,5]. There are, in total, 
65 countries along the Belt and Road, which run through Asia, Europe, and Africa, with an active East Asian economic circle and a developed European economic circle. In terms of economic development, countries along the "Belt and Road" are mostly low-income middle-income countries [6]. Through the Belt and Road Initiative, the number of cross-border e-commerce trade in countries cooperating with China is gradually increasing [7]. The top three export commodities were electronic and electrical equipment and parts (which exported US $\$ 116.59$ billion) machinery and appliances (which exported US\$92 billion), and steel products (which exported US $\$ 23.72$ billion).

As an official policy, One Belt One Road is overseen by China's National Development and Reform Commission (NDRC), Ministry of Foreign Affairs, and Ministry of Commerce under sanction from the State Council, the nation's chief administrative body [8]. The Belt-Road initiative represents China's official policy for achieving 'Sustainable Development Goals' [8] and enhancing global supply chains, primarily through infrastructure projects throughout the developing and parts of the developed world. China mainly provides infrastructure construction, energy construction, capacity cooperation, national basic services, investment and acquisition, import and export trade, and technology export services for countries along the "Belt and Road" [9].

With Chinese government support, cross-border e-commerce is booming in China. By 2015, China had more than 200,000 enterprises engaged in cross-border e-commerce, as well as over 5000 e-commerce platforms [10], and the overall transaction scale of cross-border e-commerce (including retail and B2B) reached RMB 7.6 trillion in 2017 [11]. iResearch (2018) [12] estimates that cross-border e-commerce will maintain its momentum for several years and will be a significant component of the country's foreign trade volume. The Ministry of Commerce said that China's cross-border e-commerce network covers 220 countries and global regions. However, some challenges emerged during the development, such as logistics, the efficiency of customs clearance, electronic payments, and tax refunds.

Logistics, which consists of warehousing, sorting, packaging, and distribution, play a significant role in cross-border e-commerce transactions since it links sellers and buyers, and supply and demand [13]. At present, overseas warehouses and bonded warehouses are popular among main-stream logistics solutions. Some cross-border e-commerce companies are building their own overseas warehouses, yielding business model innovations and evolution in their business ecosystems [14].

Tansley (1935) [15] first proposed the 'ecosystem' concept and emphasized the indivisibility of organisms and the physical environment, regarding them as a whole system. Inspired by this proposal, Moore (1993) [16] put forward the concept of the 'business ecosystem', which refers to an economic community that creates value for customers and consists of the interactions among organisations and individuals, including suppliers, lead producers, competitors, and other stakeholders. He also emphasizes that we must view a company as part of a business ecosystem involving various industries, rather than as a member of a single industry.

Business model innovations can create competitive advantages, and numerous studies analyse business model innovations in the supply chain management (SCM) context $[17,18]$. However, to the best of our knowledge, very few studies consider this in the cross-border e-commerce context and view supply chain innovation (SCI) as the core of business model innovation. We call this view Supply Chain-Based Business Model Innovation. Specifically, this study attempts to answer the following research question:

\section{How does SCI contribute to business model innovation in cross-border e-commerce?}

To answer this research question, we draw insights from Zongteng, a cross-border e-commerce company that was one of the first to conduct cross-border e-commerce in China. This research contributes to the SCM literature by adopting both the business ecosystem life cycle and business model canvas to analyse supply chain based business models in depth. In addition, we develop six propositions detailing the mechanisms of supply chain-based business model innovation. 
This paper proceeds as follows. Section 2 reviews the literature and introduces the theoretical foundation. Section 3 explains the research methodology. Section 4 presents the findings of Zongteng's business model innovation. Based on these findings, Sections 5 and 6 analyse and discuss the business ecosystem and business model innovation with SCI at their core. Section 7 concludes the theoretical and practical implications and notes this study's limitations.

\section{Literature Review}

This section sets the theoretical foundation of this research. We reviewed the literature on SCI in cross-border e-commerce, business model innovation, and business ecosystems.

\subsection{Supply Chain Innovation (SCI) in Cross-Border E-Commerce}

Supply Chain Innovation is 'a change (incremental or radical) within the supply chain network, supply chain technology, or supply chain processes (or combinations of these) that can take place in a company's function, within a company, in an industry or in a supply chain in order to enhance new value creation for the stakeholder' [19] (p. 8).

SCIs are not static elements, but are typically triggered by a company's dynamic interactions with their business environments. They may also result from efforts to better articulate a company's value proposition to identify new market segments or to redefine the structure of the value chain to gain an advantage over rivals [20]. According to Arlbjørn et al. (2011) [19], a Supply Chain Innovation (SCI) model contains the three elements of business processes, technology, and structure (Figure 1).

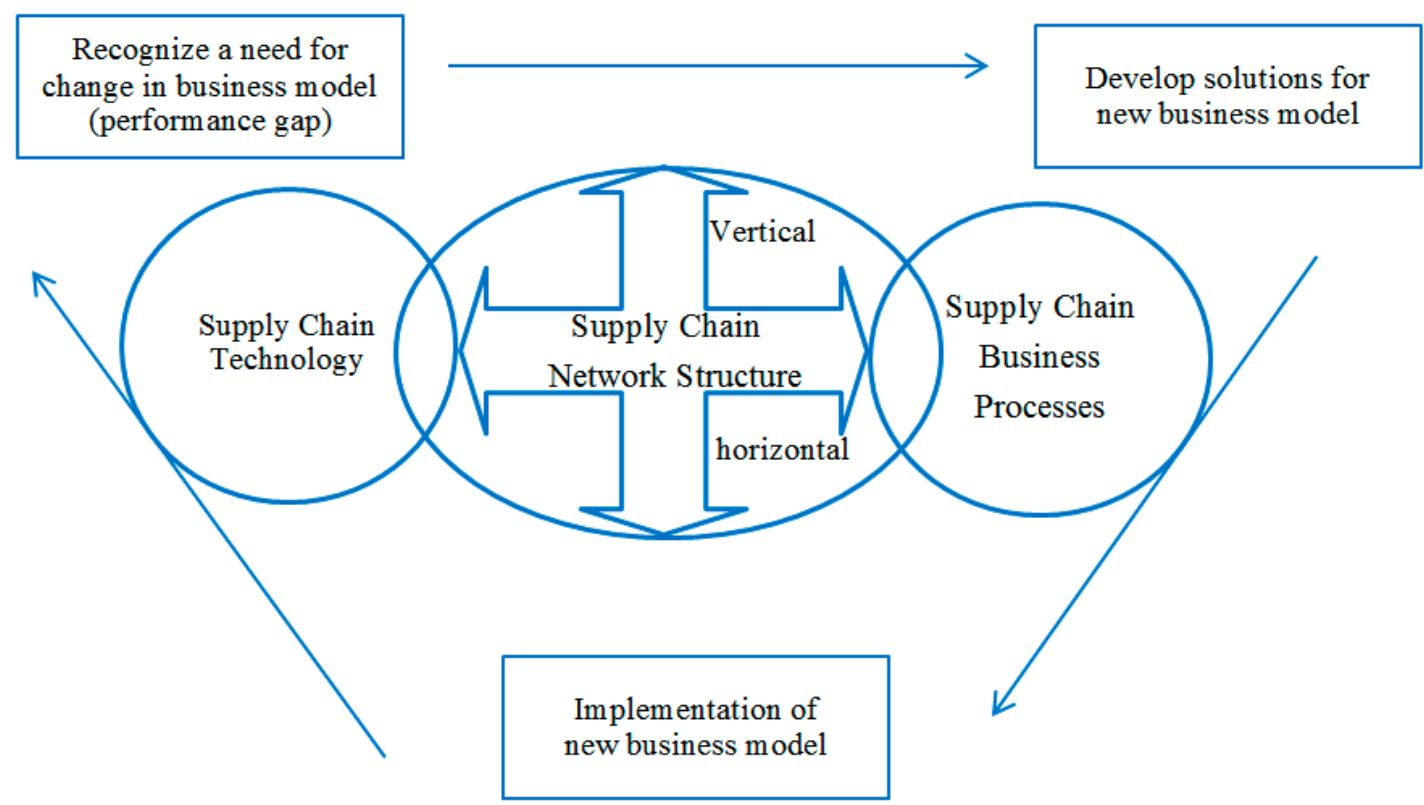

Figure 1. The elements of supply chain innovation (Source: Arlbjørn et al., 2011).

Business processes are the activities that produce a specific output of value to the customer, such as order fulfilment and supplier relationship management. Because process management techniques focus on continuous improvement in routines and variation reduction, their increased use in an organisation affects the balance between exploratory and exploitative innovation as organisational learning [21]. Supply chain technology [22] improves SCM, especially in logistics capabilities [23], such as e-procurement, RFID, demand planning tools, and, more recently, blockchain technology [24]. Supply chain network structure innovation includes both vertical and horizontal elements; that is, of the company and its supply chains partners, such as collaboration, distribution channels, logistics outsourcing, and supply complexity. Supply chain network structure innovation improves the 
evolution of the business ecosystem. We consider logistics outsourcing as a vertical network structure innovation in an e-commerce context.

Logistics plays an important role in international business $[25,26]$. An effective logistics strategy can help reduce costs and access foreign markets [27]. Firms must consider flexibility, accuracy, and speed when looking for an appropriate logistics solution for the e-commerce industry [28]. E-commerce companies tend to have both third-party logistics providers (3PLs) and their own logistics systems. Nica (2015) [29] states that e-commerce changed purchasing behaviours and thus brought challenges for logistics service providers. He also points out that China's economic expansion increases the demand for logistics services and creates challenges for operators.

Liu et al. (2015) [13] note that the rapid development of cross-border e-commerce provides a promising opportunity for logistics, while at the same time cautioning that 3PLs in China still cannot offer sufficient logistics services to enable cross-border e-commerce. The authors identify four main problems in cross-border e-commerce logistics in China: insufficient supportive policies, a mismatch between the speed of logistics development and the demand for cross-border e-commerce, incomplete support facilities, and a lack of professional 3PLs specialized in cross-border logistics. In addition, they offer six suggestions to deal with these problems: forming strategic alliances with other e-commerce companies, adopting overseas warehousing capabilities, promoting professional 3PLs, improving infrastructure construction, perfecting legal mechanisms, and enhancing supportive policies (ibid.).

Larger companies have thus developed their own logistics capabilities [29]. Companies such as JD.com abandoned external logistics and developed their own logistics system [30]. Since 2017, JD logistics international has established more than 110 overseas warehouses on five continents and provides overseas brands with cross-border logistics services, including overseas warehousing, international transportation, cross-border bonded warehouses, and domestic distribution. JD established strategic partnerships with partners such as eBay, Lotte, Rakuten, and Kao Group. The business involves more than 40 countries and regions with more than 3 million SKUs. Logistics capability acquisition occurred due to the increasing importance of logistics to a company's profitability. Internalizing this capability carries less risk and provides greater control. There are also concerns that this approach increases costs, investments, and obligations [31], which may affect the expansion of the company's core business.

\subsection{Business Model Innovation}

There are many definitions of the term business model. Some researches define it as the way a firm generates revenues [32,33], and believe that it provides guidance on how to generate profits [34-36]. Some others also view it from a strategic perspective [37] and think of it as a logical framework to realise an operation $[20,38,39]$.

For this study, we adopt Osterwalder and Pigneur's (2010) [39] (p. 75) definition, in which a business model articulates how the organisation earns a profit and thus represents the plan for the strategy to be implemented. They also developed the Business Model Canvas tool and identified nine components of business models. An organisation aims to solve problems and satisfy the needs of one or several customer segments with value propositions delivered through channels of communication, distribution, and sales, which generate revenue streams. It needs to build and maintain relationships with each customer segment. It requires key resources to deliver value by conducting key activities. Additionally, an organisation builds key partnerships through outsourcing or cooperation. The previous eight building blocks determine the cost structure, which is the ninth block (ibid.) (Table 1).

Business model innovations changed entire industries and reallocated value [40]. A business model innovation is the implementation of a new business model in an organisation and a new logic of how the organisation creates and captures value [41]. It is a process of coordination involving voluntary and emergent changes in the core components of the business model, including resources and competencies, organisational structures, and value propositions [42]. 
Business model innovation is an increasing priority for organisations to replace or complement their innovation in products or processes [43]. Business model innovations, together with operational and product or service innovations, help organisations create competitive advantages [44]. Business model innovation not only helps identify underutilized resources to capture future value, but also makes the organisation competitive and prohibits competitor imitation [43]. It also contributes to higher returns on equity, especially for organisations with more alliance experience [45]. Continuous business model innovation creates new processes for innovation and improvement, thus providing companies with constant competitive advantages [46].

Table 1. The nine elements of a business model (Osterwalder and Pigneur, 2010).

\begin{tabular}{|c|c|}
\hline Components & Description \\
\hline Customer segment & Partners/Software distributors \\
\hline Value propositions & $\begin{array}{l}\text { ICT enabled EI-Enterprise Interoperability (economic Server OS; } \\
\text { document management software; communications platform) }\end{array}$ \\
\hline Channels & Partner network \\
\hline Customer relationships & Global Business-to-Business Customized \\
\hline Revenue streams & Software sales; Software implementation and support services; training \\
\hline Key resources & $\begin{array}{l}\text { Innovation know-how; Sales competence; ICT enablers; Enterprise } \\
\text { interoperability competence }\end{array}$ \\
\hline Key activities & $\begin{array}{c}\text { Software manufacture; Software sales to partners; Software implement } \\
\text { services; New product development }\end{array}$ \\
\hline Key partners & $\begin{array}{c}\text { Consultancy for EU projects; Innovation partners: innovation laboratory } \\
\text { and faculty of sciences }\end{array}$ \\
\hline Cost structure & $\begin{array}{l}\text { Software development(innovation); Sales and Marketing; customer support } \\
\text { (after-sales) }\end{array}$ \\
\hline
\end{tabular}

Business model innovation is key to corporate change through the commercialisation of ground-breaking ideas and eventually new business models $[47,48]$ to follow opportunities that complement product or process innovations [43]. Business model innovation refers to changes to the firm's activity system [49], the 'design of organisational structures to enact a commercial opportunity' [50] (p. 99), or the elements that link innovation and value creation [20], thereby translating technical innovation into commercial performance [51]. It involves adding and linking novel value activities through integration at different levels in new ways.

\subsection{Business Ecosystem}

Moore [52] (p. 2) defined a business ecosystem as 'an economic community creating value for customers that comprises interacting organisations and individuals involving suppliers, lead producers, competitors, and other stakeholders'. In a business ecosystem, companies coevolve capabilities related to an innovation through cooperation and competition to support new products, meet customer needs, and assimilate future innovations [52]. Iansiti and Levien [53] (p. 1) define a business ecosystem as 'a loose network being comprised of suppliers, distributors, outsourcing firms, makers of related products or services, technology providers and other organisations, which influence and are influenced by the production and delivery of a company's products or services'.

Each organisation and individual participating in a business ecosystem share a common fate, so the health of a business ecosystem is significant [53]. Iansiti and Levien (2004) [53] propose a framework for evaluating the health of a company's ecosystem by focusing on the dimensions of productivity, robustness, and niche creation. The authors further identify four types of companies in the ecosystem at the firm level: q keystone player, niche player, physical dominator, and value dominator. A keystone player is likely to create and share value within the business ecosystem by developing a platform, but does not create value directly. A niche player focuses on its own expertise and innovation, acting as the primary value creator. A physical dominator aims to integrate a large proportion of a network, which will lead to the disappearance of a business ecosystem. A value 
dominator does not contribute to the business ecosystem but grabs as much value as possible, which will eventually destroy the whole ecosystem [53]. Hartigh and Asseldonk (2004) [54] integrate these four roles into three categories: shaper, adapter, and opportunist. Similarly, Iyer et al. (2006) [55] and Rong (2011) [56] develop three roles in a business ecosystem: bridge, hub, and broker; and initiator, specialist, and adopter, respectively.

A business ecosystem is not set in stone; rather, it is dynamic and co-evolves with its environment. Moore (1993) [16] proposes four evolutionary stages in the development of every business ecosystem: birth, expansion, leadership, and self-renewal/death. Business ecosystems are complex evolving systems (CES) with ten characteristics: self-organisation, emergence, connectivity, interdependence, feedback, far from equilibrium, space of possibility, co-evolution, historicity and time, and path-dependency [57]. Further, Rong (2011) [56] updates the business ecosystem lifecycle by dividing it into five phases: emerging, diversifying, converging, consolidating, and renewing. MacCarthy et al. (2016) [58] define the supply chain lifecycle as four stages following Moore (1993) [16] and identify six factors that interact and may affect a supply chain over its lifecycle. This study adopts four stages to describe the life cycle of Zongteng's business ecosystem.

\section{Methodology}

Given the limited research on business innovation in the cross-border e-commerce supply chain context and our 'how' research question [59], we adopted a single case study method. In this sense, the exploratory case study is considered an appropriate research strategy to capture the phenomenon under investigation within its complex context by relying on several sources of evidence [59]. We aim to explore the business innovation dynamic process to answer the research question of how SCI contributes to business model innovation in cross-border e-commerce. By using a single case study, we adopt a retrospective longitudinal case study approach and trace the analysis back to the Zongteng establishment in 2007 by asking interviewees for their recollections and by scrutinizing secondary data (company documents and open online resources) on the evolution of the business model. We follow the processes recommended in the operations management literature to conduct case study research and ensure rigour $[60,61]$.

\subsection{Case Selection}

Zongteng, founded in November 2007 with more than 1000 members, is a well-known cross-border e-commerce company in China. In 2013, the firm's sales exceeded 1 billion RMB, and it maintained a high annual growth rate of nearly $10 \%$ in recent years. In 2016, the firm's total sales volume was more than 1.7 billion RMB (over 240 million U.S. dollars at the average exchange rate in 2016). Based in Fuzhou, Zongteng's headquarters are the administrative centre, which involves commodity exploitation, procurement, sourcing, sales, finance, human resources, and information technology (IT). The Appendix provides the organisational structure. Zongteng has purchasing centres in Shenzhen, Guangzhou, and Yiwu, and overseas warehouses in North America, Europe, Asia, and Australia.

In 2017, Zongteng had 1700 employees. Zongtong set up an Operations Centre consisting of the BI section and platform operation, with over 100 information system development programmes. Zongteng established an IT-based platform, including Enterprise Resource Planning, Warehouse Management System, Process Control System, Learning Management System, Supplier Relationship Management, Instant Messenger, Customer Service Management, Customer Relationship Management, and Freight Management System. In 2014, it entered the logistics business. Their outstanding performance attracted collaboration with the United States Postal Service, France Post Express, UPS, and FedEx. At the same time, they began to focus on the overseas warehouse business. In 2016, the monthly shipments of their overseas warehouse exceeded 2 million bills and the monthly number of packaged logistics exceeded 1 million bills. In 2017, they formed an overseas warehouse network and dedicated line network covering developed markets. The overseas warehouse area reached 
nearly 200,000 square feet and became China's leading overseas warehousing company. According to Li Cong, deputy general manager of Zongteng, 'Our firm is the largest in the area, the first in shipment, and the first in service capacity among the cross-border e-commerce companies. At the same time, our e-commerce business is deeply based on the supply chain and achieved high-quality growth'.

Due to their outstanding achievement, they earned the Best GMV Award from eBay in 2013 and won the National E-commerce Model Enterprise award in 2015 and 2017 from the Ministry of Commerce. In 2018, it obtained investments by a number of institutions and industry leaders, such as Fosun Capital and GLP. In the business innovation and transformation stage, Zongteng made decisions conducive to the company's development, especially in terms of its logistics business innovation performance, and won recognition from its partners and investors. Thus, we selected this company as an outstanding case to explore our research question.

\subsection{Data Collection}

We collected data via multiple approaches, including semi-structured interviews, informal conversations, observations during multiple site visits, and secondary data from internal documents, the Internet, and industry reports. Field notes, including observation and reflection notes, were taken after each site visit.

We rely on four sets of primary and secondary data sources $[62,63]$ to explore the connection between the advancements of SCI, the business model, and the business ecosystem. In line with the exploratory nature of the research, data collection followed a loose timeline through which there has been some overlap with data analysis, a common feature of theory building via case studies [64]. As a first step, we inspected the literature to gather information on (i) the technological changes and the advancement of the business model, (ii) the patterns of new supply chain structure, and (iii) the evolution of the business ecosystems. These secondary sources cover a timeframe of 11 years (2007-2018). Secondly, we also consulted materials on site and had informal discussions with cross-border e-commerce practitioners and academic researchers in China. Thirdly, we carried out semi-structured interviews with chief executives and senior managers of different departments within Zongteng.

Five senior Zongteng managers were interviewed for between 1 and $2 \mathrm{~h}$, with some of them interviewed twice or more. All interviews were recorded and transcribed. The interviewees included the Deputy General Manager, Chief Operating Officer, Chief Human Resources Officer, Human Resources Manager, and Administrative Manager. The Deputy General Manager and Chief Operating Officer were interviewed twice. Table 2 provides basic information about the case company. Besides the interviews, we also visited six independent stores involved in cross-border e-commerce that use Zongteng's online portal and two of Zongteng's self-run online malls. Together with the interviews and investigations, the authors collected information on Zongteng's history, business classification, and operations.

Table 2. The list of interviewees, their job titles and organisations.

\begin{tabular}{ccccc}
\hline Number & Company & Title & Interview Method & Number of Interviews \\
\hline 1 & Zongteng & Deputy General Manager & Face to Face & 2 \\
2 & Zongteng & Chief Operating Officer & Face to Face, Telephone & 2 \\
3 & Zongteng & Chief HR Officer & Telephone & 1 \\
4 & Zongteng & HR Manager & Face to Face & 1 \\
5 & Zongteng & Administration Manager & Face to Face & 3 \\
\hline
\end{tabular}

\subsection{Coding and Data Analysis}

We adopted qualitative data analysis techniques for this research. In the first step of the analysis, we coded the interview transcripts and observations from the online stores and malls to identify Zongteng's business models and business ecosystem. In the second step, we examined how Zongteng 
innovated its business models and built its business ecosystem. We used the critical incident analysis technique to identify the first three evolutionary phases of its business ecosystem with different business models, and used this to forecast the next stage of its business ecosystem and the associated new business model. We used critical incident analysis to identify critical, influential, or decisive events in the course of the process [65] and tools such as Ecosystem Mapping (Partnering Resources) and the Business Model Canvas to illustrate the relationship between Zongteng and its stakeholders, and the building blocks of each business model. We derived the business ecosystem map and the nine basic building blocks of a business model from the interview transcripts and the information from the Internet. Thus, we analysed the constructs of the business ecosystem, SCI, and business model innovation.

\section{Case Description}

In this section, we provide the background on the company's core business models and ecosystem.

\subsection{Core Business Models}

The core business consists of direct suppliers, core contributors, and distribution channels [52]. Zongteng has five core businesses: exports, imports, freight forwarding, overseas warehousing, and bonded warehouses.

\subsubsection{Export Sales Business}

In November 2007, Zongteng started its export business on eBay and then expanded to Amazon, Aliexpress, and Wish. In 2009, it launched its own B2C mall (Tmart.com) to carry out export business. Zongteng's product portfolio has 15 main product lines including digital accessories, home furnishing, toys, clothing, tablet computers, outdoor equipment, automobile accessories, beauty products, games, security and protection products, and other product series with more than 150,000 SKUs and 5000 suppliers. However, after focusing on only high-profit items, they streamlined their offering to 30,000 SKUs in 2017.

\subsubsection{Import Sales Business}

In recent years, accompanied by a series of favourable policies for cross-border e-commerce imports issued by the Chinese government and the increasing domestic demand for foreign products, the import business experienced rapid growth. According to the Deputy General Manager of Zongteng, traditional foreign trade is outdated and is now being replaced by a complex supply chain with many layers of intermediaries. In addition to the rapid development of import e-commerce, the low credibility of domestically produced food, medicine, and cosmetics, especially products for maternity and baby needs relating to the melamine scandal (BBC News, 2009), as well as increasing brand awareness, fuelled this trend.

In 2014, Zongteng built the B2C platform Lomon.com and a self-run B2B2C distribution platform haitaole.com on Tmall International, which belongs to the Alibaba Group. The stores in these malls are leaders in their respective categories. For example, the Tmart store is one of the top 3 of 230 stores selling mother and baby products, focusing on European milk powder and Japanese diapers. Other stores like Lomon mainly sell imported products such as milk powder and mother and baby items from Germany. Haitaole provides other domestic cross-border e-commerce companies with one-stop services, including overseas procurement, storage management, order processing, picking and packaging, and delivery to their customers. Haitaole's categories include mother and baby, health care, cosmetics, food and drinks, clothes, bags, shoes, digital products, coffee, and tea. 


\subsubsection{Freight Forwarding Business}

In 2014, Zongteng introduced a new business revenue source: freight forwarding. Based on years of close cooperation with major postal companies (e.g., China Post, FedEx, Belgian Post, Royal Mail, Colissimo, Japan Post, and Australia Post) and courier companies (e.g., DHL), as well as experience in delivering cross-border goods, Zongteng set up its freight forwarding business to offer customs, logistics, storage, and reverse logistics services to small and medium-sized e-commerce companies. The freight forwarding business includes international sea and air express transportation and 'last mile' delivery. For instance, Zongteng arranges airfreights to transport goods from mainland China to Hong Kong or Taiwan, or from Hong Kong or Taiwan to the U.K. with Royal Mail to deliver the parcels after customs clearance. In 2016, the volume of the freight forwarding business was 100 million packages per month.

According to the customer's order information, Zongteng can provide different solutions by considering different sales platforms (Amazon, eBay, or Wish, etc.), the destination country, the contents of services (tracking, compensation, re-sending, etc.), price, quantity, and characteristics of the goods, the weather, freight rates, and other indicators to better combine different logistics transportation and distribution methods. For example, if the e-commerce companies sell goods on Wish with Europe as the destination, they choose 'Parcel Post + services' (transport code: BPA) and collaborate with Belgian Post. After filling in the tracking number, they can obtain a week's advance loan qualification. Furthermore, if the goods are lost, they can help claim compensation.

\subsubsection{Overseas Warehousing Business}

In November 2007, Zongteng's first overseas warehousing and logistics centre was established in the U.S. In March 2015, they began focusing on overseas warehouse operations. In 2016, the volume of the overseas warehousing business was 200 million packages per month. By the end of 2017, they established 14 warehouses, including 5 in the U.S., 3 in the U.K., 2 in Germany, 2 in Japan, 1 in Australia, and 1 in Taiwan.

To build an efficient network of worldwide overseas warehouses, Zongteng developed its overseas warehousing businesses, which include third-party overseas warehousing for medium-sized cross-border e-commerce companies and transhipment services for individuals. Through overseas warehouses, medium-sized cross-border e-commerce companies can not only reduce barriers to customs clearance, but also lower storage and operating costs. At the same time, local delivery and distribution can reduce the transfer process and earn more trust from on-online consumers. Sales localisation can also avoid trade barriers in some target markets.

In addition, cross-border e-commerce firms can achieve secondary distribution capabilities through the overseas warehouses, which is a useful complement to reverse logistics capabilities. First, for obsolete cargo accumulated in overseas warehouses, based on the demand information collected from other markets, they are transported to overseas warehouses with new target markets that have demand and are sold through e-commerce channels for repackaging, sorting, and distribution. Second, cross-border e-commerce firms can also gain logistics visualisation, such as package tracking, to provide re-sending and reassignment services.

\subsubsection{Bonded Warehousing Business}

Importers gain several advantages by using bonded warehouse storage, which makes this a popular option in many ports worldwide. Governments have different laws about how such warehouses can be administered and who can use or operate one. The U.S. definition of a customs bonded warehouse is 'a building or other secured area in which imported dutiable merchandise may be stored, manipulated, or undergo manufacturing operations without payment of duty for up to 5 years from the date of importation'. Title 19, United States Code (U.S.C.), section 1555 defines how to establish bonded warehouses and 19 CFR 19 regulates bonded warehouse operations. The General 
Administration of Customs of China (Customs Administration Order No. 105, No. 198, No. 227, No. 235) issues regulations covering bonded warehouse operation and bonded cargo.

In 2017, the Zongteng network of bonded warehouses consists of warehouses in Tianjin, Hangzhou, Ningbo, Guangzhou, Chongqing, and Hong Kong, which cover the majority of China. In peak periods, a single bonded warehouse will face congestion, leading to low efficiency. However, the network of multiple warehouses effectively solves this problem. In addition, due to the different policies and regulations in different areas, the network increases the categories of goods that the company can import.

Bonded warehouses and customs clearance services mainly provide cross-border e-commerce platforms with integrated services for domestic bonded area stocking, bonded warehousing, and direct customs clearance, sorting, packaging, and delivery from bonded warehouses when orders are created. The business process for bonded warehouses has several steps. The goods arrive at the shore for customs clearance inspection, the goods are sent to the customs supervision warehouse, merchants sell these products, the data goes through the pilot platform to declare the shipment to customs, the shipments undergo a customs audit, and the goods are delivered to consumers.

\subsection{Zongteng's Business Ecosystem}

To design and implement a business model, firms need to assess internal and external factors, including customers, suppliers, and the business ecosystem [51]. Zongteng created and developed its business ecosystem (Figure 2) in cooperation with stakeholders over its years of business model innovation.

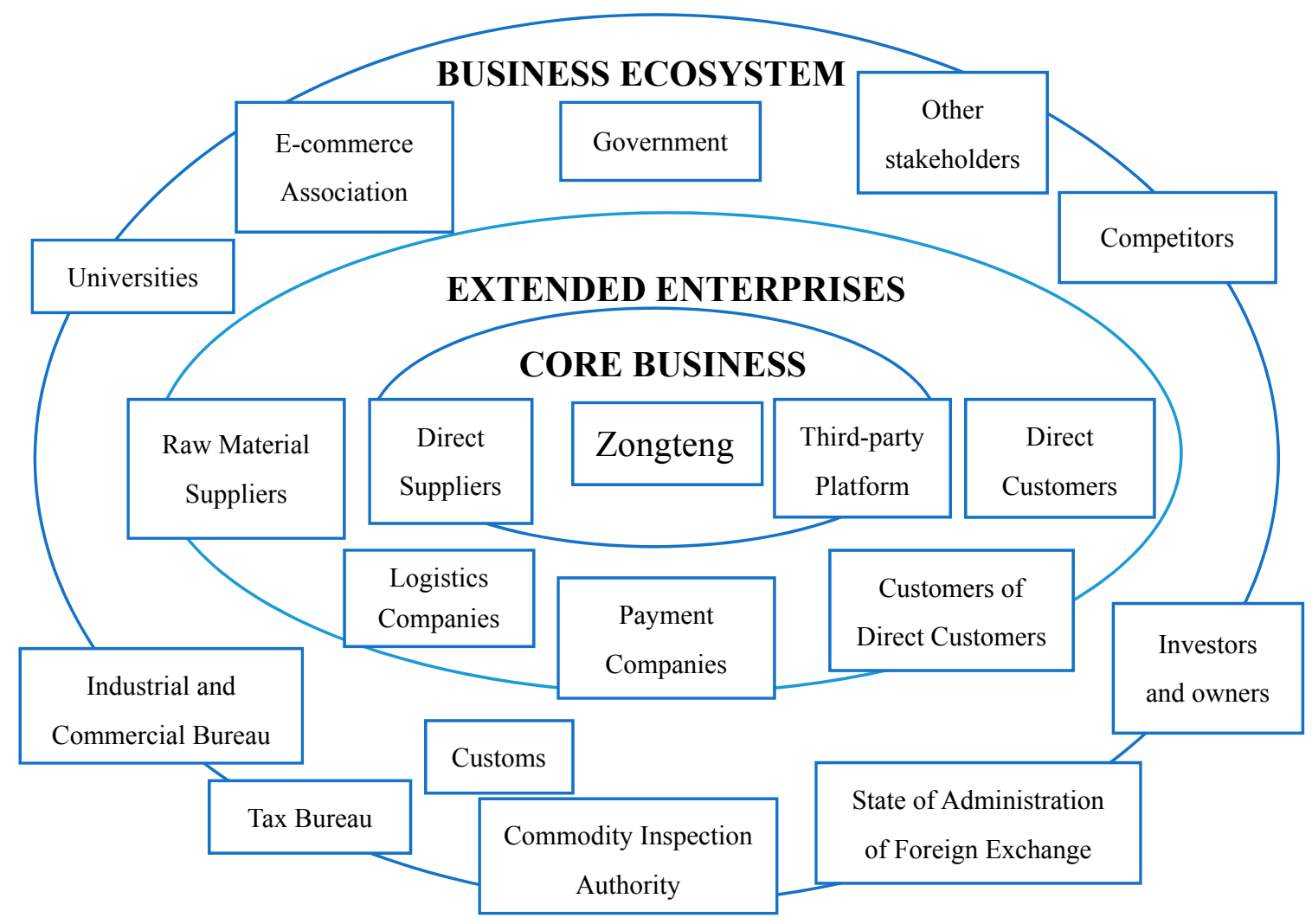

Figure 2. The business ecosystem of Zongteng.

Zongteng's business ecosystem consists of its core business, extended enterprises, and other stakeholders. The extended enterprises consist of direct suppliers, suppliers of complementary products and services, direct customers, and customers of direct customers [52]. Hence, its extended enterprises include raw material suppliers, payment companies, logistics companies, and other 
indirect customers. Raw material suppliers are upstream direct suppliers from which Zongteng purchases products. Payment companies offer payments and receipts services for online shoppers and cross-border e-commerce companies. In particular, third-party payment platforms such as PayPal greatly enhance the efficiency of cross-border transactions. Logistics companies are key extended enterprises in cross-border e-commerce companies. The 3PLs help companies realise efficiency, flexibility, market penetration, and core competitive advantages [66]. Indirect customers are customers of other cross-border e-commerce companies that purchase goods from Zongteng.

Other stakeholders include government agencies and regulatory organisations, trade associations, investors and owners, labour unions, competitors, and others [52], even if they do not create value directly to the supply chain [56]. The stakeholders around Zongteng include the government, e-commerce associations, universities, the Industrial and Commercial Bureau, the Tax Bureau, customs, the Commodity Inspection Authority, the State of Administration of Foreign Exchange, investors and owners, competitors, and so on. The e-commerce association publicises and implements relevant policies and regulations, reports requirements for members, and represents the industry in front of external stakeholders such as government departments, assists the government in drafting regulations and carrying out standards, regulates market behaviour, and organises meetings for members to promote mutual understanding and common development. Universities nurture talent specialised in cross-border e-commerce for the industry. Zongteng established partnerships with several higher education institutions like Fuzhou University and Minjiang University, providing sites to enhance students' industry experience.

\section{Case Analysis}

\subsection{Supply Chain-Based Business Model Innovation in the Evolution of the Business Ecosystem}

A business model can articulate the logic of how an organisation creates, delivers, and captures value [39]. Zongteng had only its export business in its infancy and later diversified into various businesses, such as import, freight forwarding, overseas warehousing, and bonded warehousing. The addition of these types of businesses represents the innovation and evolution of its business models.

Furthermore, the business ecosystem tends to go through four evolutionary stages: birth, expansion, leadership, and self-renewal [16]. The business ecosystem of Zongteng evolved from birth to leadership in accordance with its business model innovation from exports to overseas and bonded warehousing. Next, we combine the evolution of the business ecosystem [52] and the Business Model Canvas [39] approach to analysing the Zongteng's business model innovation in the evolution of the business ecosystem.

\subsubsection{Birth}

In the birth stage (for Zongteng, from 2007 to 2010), companies aim to give a value proposition to segment customers through cooperation [16]. Successful companies are those who best define and implement value propositions [16]. During that period, Zongteng identified the commercial opportunity of the export business and built its business model (Table 3) to provide inexpensive, high-quality products (mainly in digital accessories) in China to foreign online shoppers. Zongteng then profited from the price differences. Zongteng started its export business with a clear definition of its value proposition, namely to target foreign markets. Companies often provide similar products with lower prices to meet the demands of price sensitive customer groups and create value for them [39]. Since Zongteng was not equipped with sufficient resources to conduct its business in its infancy, it had to rely on third-party platforms to obtain potential customers. Although using a partner's channel may result in lower revenue, a company can expand the scope of its potential customers and income using the partner's strength [39]. 
Table 3. The seven business model canvas of Zongteng.

\begin{tabular}{|c|c|c|c|c|c|c|c|c|c|c|}
\hline & $\begin{array}{l}\text { Business Model for } \\
\text { Export Sales } \\
\text { Through Third- }\end{array}$ & $\begin{array}{l}\text { Business Model for } \\
\text { Export Sales } \\
\text { Through Self-Run }\end{array}$ & \multicolumn{2}{|c|}{$\begin{array}{l}\text { Business Model for } \\
\text { Imports Sales }\end{array}$} & \multirow{2}{*}{$\begin{array}{c}\text { Business Model for } \\
\text { Freight Forwarding } \\
\text { Small sized } \\
\text { cross-border } \\
\text { e-commerce companies }\end{array}$} & \multicolumn{2}{|c|}{$\begin{array}{l}\text { Business Model for Overseas } \\
\text { Warehousing }\end{array}$} & \multicolumn{2}{|c|}{$\begin{array}{l}\text { Business Model for Bonded } \\
\text { Warehousing }\end{array}$} & \multirow{2}{*}{$\begin{array}{c}\begin{array}{c}\text { Business Model } \\
\text { for Supply Chain } \\
\text { Finance (Future } \\
\text { Scenario) }\end{array} \\
\begin{array}{c}\text { Cross-border } \\
\text { e-commerce } \\
\text { companies }\end{array}\end{array}$} \\
\hline $\begin{array}{l}\text { Customer } \\
\text { Segments }\end{array}$ & $\begin{array}{l}\text { Foreign online } \\
\text { shoppers }\end{array}$ & $\begin{array}{l}\text { Foreign online } \\
\text { shoppers }\end{array}$ & $\begin{array}{l}\text { Domestic } \\
\text { online } \\
\text { shoppers }\end{array}$ & $\begin{array}{l}\text { Domestic } \\
\text { cross-border } \\
\text { e-commerce } \\
\text { companies }\end{array}$ & & $\begin{array}{l}\text { Screened } \\
\text { medium sized } \\
\text { cross-border } \\
\text { e-commerce } \\
\text { companies }\end{array}$ & $\begin{array}{c}\text { Individuals who } \\
\text { need } \\
\text { transhipment }\end{array}$ & $\begin{array}{l}\text { Screened } \\
\text { medium sized } \\
\text { cross-border } \\
\text { e-commerce } \\
\text { companies } \\
\end{array}$ & $\begin{array}{l}\text { Individuals } \\
\text { who need } \\
\text { transhipment }\end{array}$ & \\
\hline $\begin{array}{c}\text { Value } \\
\text { Proposition }\end{array}$ & Price & Price & $\begin{array}{l}\text { Accessibility } \\
\text { Cost } \\
\text { reduction }\end{array}$ & $\begin{array}{l}\text { Risk } \\
\text { reduction } \\
\text { Getting the } \\
\text { job done }\end{array}$ & $\begin{array}{l}\text { Customization, Getting } \\
\text { the job done, Sales force }\end{array}$ & Accessibility & Convenience & Accessibility & Convenience & $\begin{array}{l}\text { Cost reduction, } \\
\text { Risk reduction }\end{array}$ \\
\hline Channels & $\begin{array}{l}\text { Third-party } \\
\text { platform }\end{array}$ & Self-run online mall & $\begin{array}{l}\text { Third-party } \\
\text { platform }\end{array}$ & $\begin{array}{l}\text { Self-run } \\
\text { online mall }\end{array}$ & Web sales & $\begin{array}{l}\text { Sales force and } \\
\text { Self-run web }\end{array}$ & $\begin{array}{l}\text { Third-party } \\
\text { platform }\end{array}$ & Sales force & $\begin{array}{c}\text { Partner web } \\
\text { sales }\end{array}$ & $\begin{array}{l}\text { Sales forces, } \\
\text { Web sales }\end{array}$ \\
\hline $\begin{array}{l}\text { Customer } \\
\text { Relationships }\end{array}$ & $\begin{array}{c}\text { Personal assistance, } \\
\text { Automated services, } \\
\text { Co-creation }\end{array}$ & $\begin{array}{c}\text { Personal assistance, } \\
\text { Automated services, } \\
\text { Co-creation }\end{array}$ & \multicolumn{2}{|c|}{$\begin{array}{c}\text { Personal assistance, } \\
\text { Automated services, } \\
\text { Co-creation }\end{array}$} & Personal assistance & $\begin{array}{l}\text { Personal } \\
\text { assistance }\end{array}$ & Self-service & $\begin{array}{c}\text { Personal } \\
\text { assistance }\end{array}$ & Self-service & $\begin{array}{l}\text { Personal } \\
\text { assistance }\end{array}$ \\
\hline $\begin{array}{l}\text { Revenue } \\
\text { Streams }\end{array}$ & $\begin{array}{l}\text { Differences of } \\
\text { purchasing and } \\
\text { selling prices }\end{array}$ & $\begin{array}{l}\text { Differences of } \\
\text { purchasing and } \\
\text { selling prices }\end{array}$ & \multicolumn{2}{|c|}{$\begin{array}{l}\text { Differences of purchasing } \\
\text { and selling prices }\end{array}$} & Service fees & \multicolumn{2}{|c|}{$\begin{array}{l}\text { Customs clearance, storage, } \\
\text { operating and reverse logistics } \\
\text { services fees }\end{array}$} & \multicolumn{2}{|c|}{ Service fees } & Commission fees \\
\hline $\begin{array}{l}\text { Key } \\
\text { resources }\end{array}$ & $\begin{array}{c}\text { Overseas } \\
\text { warehouses }\end{array}$ & $\begin{array}{c}\text { Overseas } \\
\text { warehouses }\end{array}$ & \multicolumn{2}{|c|}{$\begin{array}{l}\text { Overseas warehouses, } \\
\text { Bonded warehouses }\end{array}$} & $\begin{array}{l}\text { Relationships, } \\
\text { Experience }\end{array}$ & Overseas & warehouses & \multicolumn{2}{|c|}{$\begin{array}{l}\text { Overseas and bonded } \\
\text { warehouses }\end{array}$} & $\begin{array}{l}\text { Relationship, } \\
\text { credit system, } \\
\text { cloud computing } \\
\text { and information } \\
\text { processing system }\end{array}$ \\
\hline $\begin{array}{c}\text { Key } \\
\text { activities }\end{array}$ & $\begin{array}{l}\text { Procurement from } \\
\text { domestic suppliers, } \\
\text { Operation }\end{array}$ & $\begin{array}{l}\text { Procurement from } \\
\text { domestic suppliers, } \\
\text { Operation }\end{array}$ & \multicolumn{2}{|c|}{$\begin{array}{l}\text { Procurement from foreign } \\
\text { suppliers, Operation }\end{array}$} & $\begin{array}{l}\text { Problem solving, } \\
\text { Freight forwarding } \\
\text { services, order } \\
\text { fulfilment }\end{array}$ & $\begin{array}{l}\text { Warehousing } \\
\text { fulfilment, secol }\end{array}$ & $\begin{array}{l}\text { service, order } \\
\text { dary distribution }\end{array}$ & \multicolumn{2}{|c|}{$\begin{array}{l}\text { Bonded area stocking, bonded } \\
\text { warehousing service, order } \\
\text { fulfilment }\end{array}$} & Credit rating \\
\hline $\begin{array}{c}\text { Key } \\
\text { partnerships }\end{array}$ & $\begin{array}{c}\text { Domestic suppliers, } \\
\text { Logistics companies, } \\
\text { Third-party } \\
\text { platform }\end{array}$ & $\begin{array}{l}\text { Domestic suppliers, } \\
\text { Logistics companies }\end{array}$ & \multicolumn{2}{|c|}{$\begin{array}{l}\text { Foreign suppliers, Logistics } \\
\text { companies, Third-party } \\
\text { platform }\end{array}$} & $\begin{array}{c}\text { Major postal companies, } \\
\text { Logistics companies, } \\
\text { Online sales platform, } \\
\text { regulatory agencies } \\
\text { (Customs, inspection } \\
\text { and quarantine) }\end{array}$ & $\begin{array}{r}\text { Logistics compr } \\
\text { companies, reg } \\
\text { (Customs, } \mathrm{i} \\
\text { quar }\end{array}$ & $\begin{array}{l}\text { nies, e-commerce } \\
\text { ulatory agencies } \\
\text { spection and } \\
\text { intine) }\end{array}$ & \multicolumn{2}{|c|}{$\begin{array}{l}\text { Logistics companies, } \\
\text { e-commerce companies, } \\
\text { regulatory agencies (Customs, } \\
\text { inspection and quarantine) }\end{array}$} & $\begin{array}{l}\text { Financial } \\
\text { institutions }\end{array}$ \\
\hline $\begin{array}{c}\text { Cost } \\
\text { structure }\end{array}$ & $\begin{array}{l}\text { Management fees, } \\
\text { Logistics fees, } \\
\text { Construction fees, } \\
\text { Commission fees }\end{array}$ & $\begin{array}{l}\text { Management fees, } \\
\text { Logistics fees, } \\
\text { Construction fees, } \\
\text { Development fees }\end{array}$ & \multicolumn{2}{|c|}{$\begin{array}{l}\text { Management fees, Logistics } \\
\text { fees, Commission fees, } \\
\text { development fees }\end{array}$} & $\begin{array}{l}\text { Construction fees and } \\
\text { operation fees of } \\
\text { transport fleet } \\
\text { management fees of } \\
\text { warehouses }\end{array}$ & $\begin{array}{l}\text { Manage } \\
\text { constru }\end{array}$ & $\begin{array}{l}\text { ment fees, } \\
\text { ction fees }\end{array}$ & \multicolumn{2}{|c|}{$\begin{array}{l}\text { Management fees, } \\
\text { construction fees }\end{array}$} & Construction fees \\
\hline
\end{tabular}


The stores operating on third-party platforms can provide foreign customers with online advice and answer queries in several languages, and automatically recommend products according to their consumption preferences. Furthermore, customers can also leave comments about the products, which provide references for other customers and co-creates value. The key activities include procurement from domestic suppliers and operating stores, while the key partnerships are with domestic suppliers and logistics companies as well as cross-border e-commerce third-party platforms. The main costs are the management fees, logistics fees, costs to construct overseas warehouses, and commission fees to third-party platforms. Zongteng's business model represents those of companies working through third-party cross-border e-commerce platforms.

\subsubsection{Expansion}

During the expansion stage (for Zongteng, from 2010 to 2014), business ecosystems seek to broaden their territories [16]. Companies in the expansion stage will have new offerings and cover a broader market with the support of suppliers and partners [16]. On the one hand, Zongteng continuously extended its export business, including broadening its range from digital and electronic accessories to 15 categories, building relationships with more than 5000 suppliers, and innovating a new business model (Table 3). The company built a self-run online shopping mall called Tmart to reduce intermediate links and face the foreign market directly based on its experience and customer acceptance.

Since business model innovation can be derived from many potential sources [51], Zongteng innovated its export business model by exploring a new sales channel. Self-owned channels can help companies to generate higher profit, though the construction and operation costs are high [39]. At this stage, Zongteng had shops on four cross-border e-commerce third-party platforms (Amazon, eBay, Wish, and Alibaba). It sold their own brand's products on Amazon, products at low prices on eBay and Aliexpress, and fashion digital products on Wish, while also selling almost all of its products on its self-run online mall. Companies need to find a balance between partner channels and its own channels, making full use of them to create a satisfying customer experience and avoid channel conflicts [39].

On the other hand, by taking advantage of overseas warehouses, Zongteng began to explore the import business (Table 3) in 2014. The import business aimed to provide domestic online shoppers with high-quality foreign products and end-to-end supply chain services to other import e-commerce companies, offering benefits such as accessibility, cost reduction, risk reduction, and getting the job done to profit from price differences. The associated sales channels are a third-party platform called Tmall and a self-run online mall named Haitaole. To better understand customers' needs and solve problems during purchasing, Zongteng set up customer service teams to offer personal assistance and automated recommendations. In particular, the stores on Tmall, like the ones on Amazon and eBay, allow customers to provide comments to give evaluations and suggestions.

In the import business, the key resources are overseas warehouses and bonded warehouses; its key activities are procurement from foreign suppliers and operating the stores and the mall; and its key partnerships are foreign suppliers, logistics companies, and third-party platforms. Compared to the export business, the main cost is almost the same, except for the cost to construct the overseas warehouse. Imports and exports have similar business models in terms of the channels, revenue stream, key activities, and key partnerships. Zongteng explored new products and acquired new import markets, which added domestic online shoppers to the customer group and foreign suppliers to the direct suppliers. In addition, the new business model resulted in a new relationship with a new e-commerce platform, Tmall. During the expansion stage, with the innovation in its business model, Zongteng built new partnerships and absorbed new stakeholders into its business ecosystem.

\subsubsection{Leadership}

In the leadership stage (for Zongteng, between 2014 and 2016), companies need to provide a promising vision to encourage the ecosystem to improve, acquire bargaining power, and ensure a robust environment for suppliers [16]. Zongteng is one of the most famous cross-border e-commerce 
companies in China and established long and friendly business relations with many other cross-border e-commerce companies, suppliers, and logistics companies. Due to long-term cooperation with its partners, Zongteng acquired significant bargaining power over both suppliers and logistics companies. Zongteng has more than 5000 suppliers in China and builds partnerships with foreign suppliers, including brand manufacturers and initial distributors, to get favourable purchase prices. In addition, Zongteng receives preferential pricing from logistics companies so it can provide below-market average prices to consumers.

At the same time, to maintain the competitive edge and make full use of resources, Zongteng developed freight forwarding, overseas warehousing, and bonded warehousing businesses. Cross-border e-commerce is closely connected with logistics, as we see in the key partnerships in both the export and import businesses. Based on years of experience and cooperative relationships with key logistics companies, Zongteng built its freight forwarding business (Table 3) to reduce logistics costs and earn significant profits. The freight forwarding business aims to provide customised cross-border logistics solutions to small cross-border e-commerce companies and help them focus on their core business. In terms of sales channels, Zongteng has its own sales teams and an official website for its freight forwarding business as well to provide personal assistance and service online. Additionally, it can also earn service fees by providing logistics solutions and freight forwarding services. The key partnerships include logistics and warehousing companies.

In order to take full advantage of overseas warehouses and create value for the whole business ecosystem, Zongteng began developing its overseas warehousing business (Table 3) to medium-sized cross-border e-commerce companies and individuals. Because they lack sufficient funds and resources, medium-sized cross-border e-commerce companies need third-party overseas warehousing companies to store their goods near the foreign market. Therefore, Zongteng provides access to overseas warehouses and offers services for storage, sorting, packaging, and dispatch. Since the market demand exceeds supply, Zongteng does not need to publicly advertise this business. Instead, they need only to screen customer companies using some standards. It offers personal assistance to medium-sized cross-border e-commerce companies to optimise their sales process. Zongteng also cooperates with China Post to offer convenient shopping experiences to domestic online shoppers who purchase from foreign e-commerce sites and need transhipment service. The extensive network of overseas warehouses has become a key resource for Zongteng. Therefore, the revenue stream is the service fees that customer segments pay and the cost structure includes the fees to manage the overseas warehouses.

To take advantage of favourable import policies, Zongteng started its bonded warehousing business (Table 3). Zongteng provides access to bonded warehouses and offers services for stocking, bonded warehousing, direct customs clearance, sorting, packaging, and delivery from its bonded warehouses when orders are created. Zongteng also cooperates with China Post to offer convenient shopping experiences for domestic online shoppers who purchase from foreign e-commerce sites and need transhipment service. The extensive network of overseas and bonded warehouses is a key resource for Zongteng. Therefore, the revenue stream is the service fees that customer segments pay and the cost structure includes the fees to manage the overseas warehouses.

\subsubsection{Self-Renewal}

During the self-renewal stage (future), companies need to work with new partners to bring new ideas and innovation to the ecosystem [16]. Zongteng managed its logistics well to build its overseas and bonded warehouses and provide customs clearance and forwarding services. The self-run import online mall Haitaole absorbs the cost of supply chain financing and bears the cost of payment terms for its customer companies, which reduces their financial pressure and risks. Online shoppers need only to pay the small and medium-sized e-commerce companies, and Zongteng will deliver the goods on behalf of these e-commerce companies. Currently, according to the Deputy General Manager, Zongteng has partnerships with financial institutions, which may enable the firm to provide supply 
chain financing services in the future, representing a new business model (Table 3). This has the potential to change its business ecosystem again.

Cross-border e-commerce companies may face financial pressure due to cash purchases and postponed receivables, which limits their development and harm their purchase capabilities. Supply chain finance relies on cooperation with financial institutions to provide financing services for cross-border e-commerce companies, especially small and medium-sized ones. According to the Deputy General Manager, Zongteng developed a cross-border e-commerce credit system to help cross-border e-commerce companies acquire more financial support at a lower access threshold and with lower risk. It can also provide small business customers with free use of ERP systems, open API ports to gain timely information symmetry and communication. They can collect customers' operating data and combe this with order information. They repeatedly verify this data using a multi-algorithm model to form an enterprise credit rating score. The company collects financial data, production data, electricity consumption, wage levels, order quantity, cash flow, assets and liabilities, investment preferences, success or failure ratio, technology level, R\&D investment, product cycle, safety stock, sales distribution, and so on to provide guarantees for these companies based on a credit rating score, and Zongteng would supervise the goods in its overseas warehouses.

Hence, financial institutions are opening to lending to the guaranteed companies. Zongteng will make significant investments to construct its platform and generate returns from the commission fees from both financial institutions and cross-border e-commerce companies. Zongteng could leverage cloud computing and information processing to create a more comprehensive business ecosystem that involves finance-related companies. The information processing capability could help optimise and upgrade the entire business ecosystem.

\section{2. $S C I$}

SCI consists of business processes, structures, and technology innovation. SCI in Zongteng exemplifies all three elements. Overseas warehouses and bonded warehouses are innovations in the logistics nodes of the supply chain and the key resources that lead to innovation in the business models. E-commerce technologies also change how firms service customers, as well as customer relationship management and order fulfilment processes. We will explain the change in the supply chain structure in more detail. Specifically, the export business can be classified into two types: direct delivery and delivery from overseas warehouses (Figure 3), while the import business can be divided into two types: direct delivery and delivery from bonded warehouses (Figure 4).

\subsubsection{Patterns of Logistics for Export}

Zongteng aimed to localise their warehouses, sales team, and R\&D to achieve a competitive advantage. For warehouse localisation, they can follow either a direct delivery pattern or a delivery from overseas warehouses pattern (Figure 3). Overseas warehouses that forward shipments before sales and thus localise Zongteng's cross-border e-commerce, can create opportunities for business model innovation. 


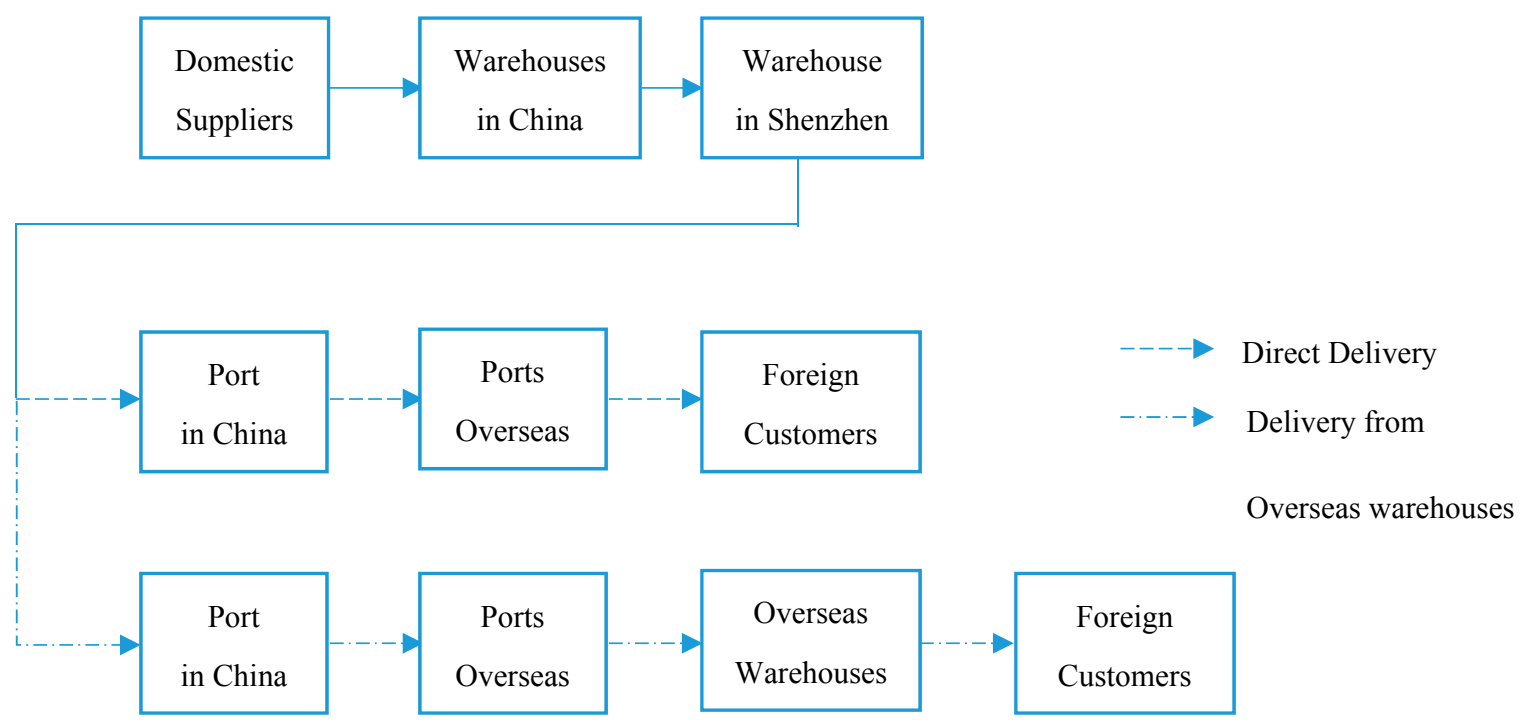

Figure 3. The different patterns of logistics for export.

On the localisation of warehouses for exports, Zongteng purchases goods from domestic suppliers, stores them in different warehouses in China, and then consolidates goods in warehouses in Shenzhen or Yiwu, China. According to the requirements of orders or the characteristics of the goods, Zongteng will decide whether to deliver goods directly to online shoppers or stock them in overseas warehouses. In the former case, goods will pass through ports in both countries and be delivered directly to customers; in the latter case, the goods will be stocked in the overseas warehouses first and dispatched from overseas warehouses to foreign customers once the order is settled. Moreover, the company's overseas warehouse helps customers achieve retail localisation by covering the functions of overseas procurement, sales, $R \& D$, and collecting consumer information. Using overseas warehouses shortens the order cycle time, reduces operation costs, broadens categories, and promotes the sales of heavy or large products like furniture worldwide. Meanwhile, using overseas warehouses also promotes the development of freight forwarding businesses.

Zongteng localised its sales team by exploring foreign distribution channels, services in several foreign languages, and settlements in local currencies. Zongteng hosts local in-house sales teams and small local distributors who reply on Zongteng's overseas warehouses and online platform and build $\mathrm{O} 2 \mathrm{O}$ offline experiential shops for consumers. Sales and distribution localisation helps Zongteng move closer to the market to capture the new consumption trends of overseas markets and avoid trade barriers to some extent. The new consumption trends will drive the product and service innovation in Zongteng and its suppliers in China.

\subsubsection{Patterns of Logistics for Imports}

According to the different key resources $[67,68]$, import businesses can be classified into a direct delivery pattern and a delivery from bonded warehouses pattern (Figure 4). Zongteng actively establishes cooperative relationships with brand manufacturers and primary dealers, procures products directly from them, and delivers goods directly from overseas warehouses or stores in the bonded warehouses to reduce logistics costs according to the different requirements of each order. Through information processing and analysis, Zongteng forecasts the popular products and stores them in the domestic bonded warehouses. Delivery from bonded warehouses reduces logistics costs and improves speed to make it similar to domestic express. 


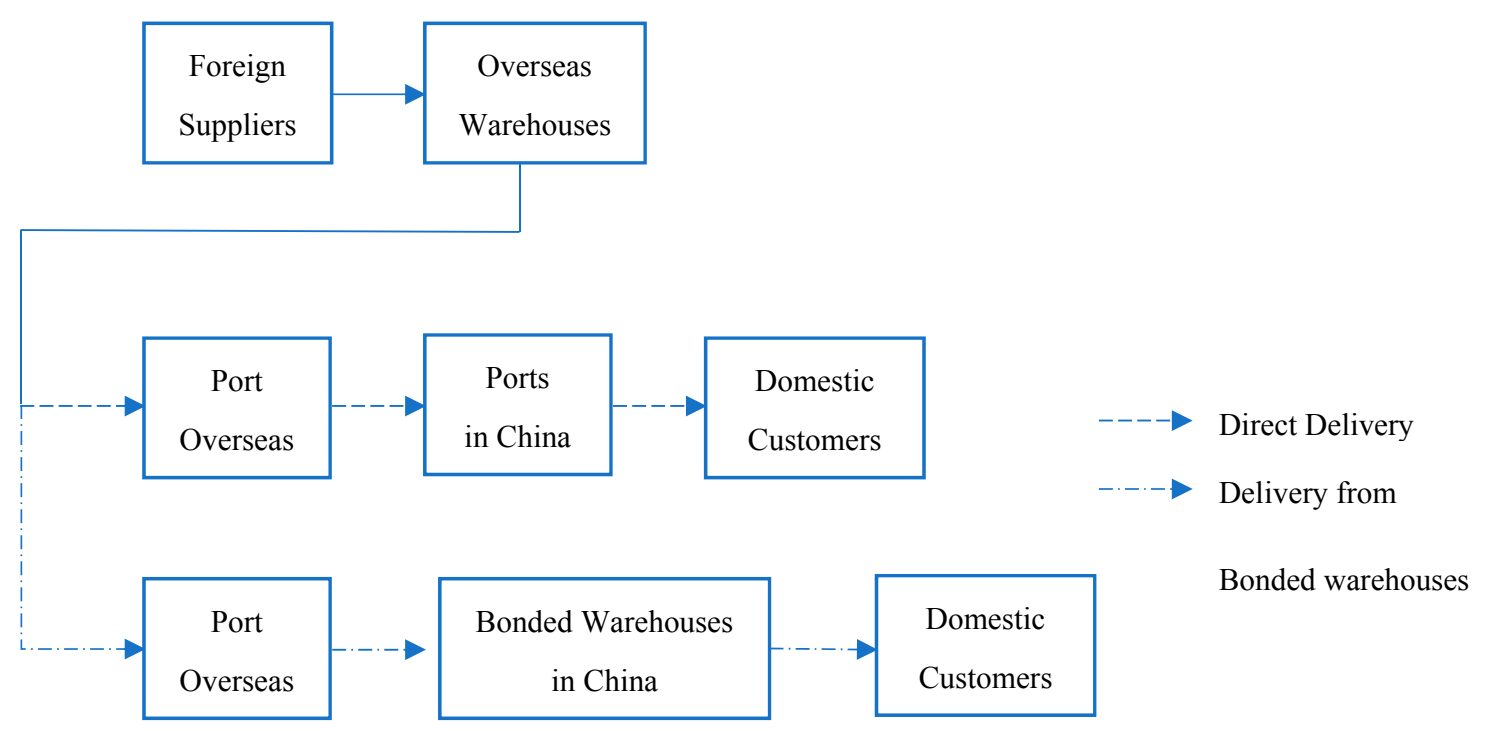

Figure 4. The different Patterns of Logistics for Import.

In the direct delivery pattern, the goods will pass through the ports in two countries and then be delivered directly to customers; in the delivery from bonded warehouses pattern, after goods passed through the ports, they will be stored in the bonded warehouses first. Once the order is settled, the goods will be dispatched from the bonded warehouses to customers.

\section{Discussion}

In this section, we further clarify the findings and discuss them in the context of the existing literature.

\subsection{Supply Chain and Business Model Innovation}

SCI consists of business processes, technology, and structures [19]. We found that the Innovative nodes of logistics and the construction of overseas and bonded warehouses contributed to business model innovation. There are close links between SCI and business model innovation.

Drawing from the case, the localisation of warehousing, sales teams, and R\&D is the main innovation in the Supply Chain structure. These three elements can help cross-border e-commerce companies implement a new business model. Sales and R\&D localisation can help companies take advantage of timely market information, and warehouse localisation helps the company serve local customers better with reliable logistics management. On R\&D localisation, Zongteng optimises sales by using information processing technology. It can estimate customer behaviours and habits in advance and forecast demand by employing a large amount of consumer data, accumulated information, and analytical systems. Thus, Zongteng can place orders according to sales conditions and localise its R\&D. Supply chain process integration enables sales opportunities associated with a new product launch or the entry to a new market [69]. Using backward integration within the supply chain, Zongteng shifted its revenue stream away from price differences to product $R \& D$, which could maximise profits. The company built an $R \& D$ team at each international warehouse site to identify seasonal and obsolescent products, and to find innovative ways of using customers' inbound and outbound shipment data (e.g., supply chain finance).

Based on these findings, Table 4 summarises the business model and SCI at the different stages of the business ecosystem. 
Table 4. The business model and supply chain innovation in the Zongteng business ecosystem.

\begin{tabular}{|c|c|c|c|c|}
\hline $\begin{array}{l}\text { Ecosystem } \\
\text { Stages }\end{array}$ & & Supply Chain Innovation & Business Model Innovation & Role and Key Players in Ecosystem \\
\hline \multirow[t]{2}{*}{ Birth } & Structure & $\begin{array}{l}\text { Localisation sales team: on third-party } \\
\text { platforms } \\
\text { Localisation warehousing: oversea warehouse }\end{array}$ & \multirow[t]{2}{*}{$\begin{array}{l}\text { Export sales: Provided inexpensive products } \\
\text { with high-quality to foreign online shoppers }\end{array}$} & \multirow{2}{*}{$\begin{array}{l}\text { Role: E-tailer (dealer, agent, distributor) } \\
\text { Key players: Domestic suppliers, Logistics } \\
\text { companies, Third-party platform }\end{array}$} \\
\hline & Process & $\begin{array}{l}\text { Customer service management, Supplier } \\
\text { relationship management }\end{array}$ & & \\
\hline \multirow[t]{4}{*}{ Expansion } & Structure & $\begin{array}{l}\text { Localisation sales team: through more } \\
\text { third-party platforms and self-run online } \\
\text { shopping mall } \\
\text { Localisation R\&D: Product new brands }\end{array}$ & \multirow{2}{*}{$\begin{array}{c}\text { Export sales exploring new sales channel } \\
\text { (self-run online mall), sold own brands } \\
\text { products }\end{array}$} & \multirow{2}{*}{$\begin{array}{l}\text { Role: E-tailer (dealer, agent, distributor and } \\
\text { brand owner) } \\
\text { Key players: Domestic suppliers, Logistics } \\
\text { companies, Third-party platform }\end{array}$} \\
\hline & Process & $\begin{array}{l}\text { Customer service management, Manufacturing } \\
\text { flow management, Product development, } \\
\text { Supplier relationship management }\end{array}$ & & \\
\hline & Structure & $\begin{array}{l}\text { Localisation sales team: on third-party } \\
\text { platforms and self-run online shopping mall } \\
\text { Localisation warehousing: oversea warehouse } \\
\text { and bonded warehouse }\end{array}$ & Import sales & $\begin{array}{l}\text { Role: E-tailer (dealer, agent, distributor) } \\
\text { Key players: Foreign suppliers, Logistics } \\
\text { companies, Third-party platform }\end{array}$ \\
\hline & Process & $\begin{array}{c}\text { Customer relationship management, Demand } \\
\text { management, Supplier relationship } \\
\text { management }\end{array}$ & & \\
\hline \multirow{6}{*}{ Leadership } & Structure & Localisation warehousing: oversea warehouse & \multirow{2}{*}{$\begin{array}{l}\text { Freight forwarding: Provide international } \\
\text { sea and air express transportation and last } \\
\text { mile delivery }\end{array}$} & \multirow{2}{*}{$\begin{array}{l}\text { Role: Logistics service provider } \\
\text { Key players: Major postal companies, Logistics } \\
\text { companies, Online sales platform }\end{array}$} \\
\hline & Process & $\begin{array}{l}\text { Customer service management, } \\
\text { Order fulfilment }\end{array}$ & & \\
\hline & Structure & $\begin{array}{l}\text { Localisation R\&D: capture the new } \\
\text { consumption trends of overseas markets } \\
\text { Localisation warehousing: oversea warehouse }\end{array}$ & \multirow{2}{*}{$\begin{array}{l}\text { Overseas warehousing: Provide } \\
\text { warehousing service, order fulfilment and } \\
\text { secondary distribution }\end{array}$} & \multirow{2}{*}{$\begin{array}{l}\text { Role: Logistics service provider } \\
\text { Key players: Logistics companies, e-commerce } \\
\text { companies, regulatory agencies } \\
\text { (Customs, inspection and quarantine) }\end{array}$} \\
\hline & Process & $\begin{array}{l}\text { Customer service management, } \\
\text { Order fulfilment, Return management }\end{array}$ & & \\
\hline & Structure & Localisation warehousing: bonded warehouse & \multirow{2}{*}{$\begin{array}{c}\text { Bonded warehousing: Provide bonded area } \\
\text { stocking, bonded warehousing service, } \\
\text { order fulfilment }\end{array}$} & \multirow{2}{*}{$\begin{array}{c}\text { Role: Logistics service provider } \\
\text { Key players: Logistics companies, e-commerce } \\
\text { companies, regulatory agencies } \\
\text { (Customs, inspection and quarantine) }\end{array}$} \\
\hline & Process & $\begin{array}{l}\text { Customer service management, } \\
\text { Order fulfilment }\end{array}$ & & \\
\hline \multirow[t]{2}{*}{ Self-renewal } & Structure & $\begin{array}{l}\text { Localisation warehousing: Oversea and } \\
\text { bonded warehouse }\end{array}$ & \multirow{2}{*}{$\begin{array}{l}\text { Supply chain finance: Provide finance service } \\
\text { based on a credit system and supervise } \\
\text { guaranties inside the oversea warehouse }\end{array}$} & \multirow{2}{*}{$\begin{array}{l}\text { Role: Finance service provider } \\
\text { Key players: Financial institutions and } \\
\text { cross-border e-commerce companies }\end{array}$} \\
\hline & Process & Customer relationship management & & \\
\hline
\end{tabular}


According to the discussion and case analysis in Section 5.1, the case company's IT-based platform capabilities have a substantial effect on SCI. This capability is deeply embedded in the structure of interfirm information, logistics, and financial processes [69]. Our findings support Rai et al.'s (2006) [69] proposition that 'information flow' has the largest effect on SCI, followed by physical flow and financial flow. The SCIs are shifting from the basic localisation strategies to the complex and comprehensive service of supply chain finance. Based on this discussion, we propose our first set of propositions:

P1a: SCI (e.g., overseas warehouses, sales teams, RED localisation, and supply chain finance) contributes directly to and is the core of business model innovation in cross-border e-commerce.

P1b: SCIs shift from basic and simple formats towards complex or comprehensive ones in the business model innovation stages (e.g., from localisation strategies to supply chain finance activities).

P1c: A cross-border e-commerce companies' SCI follows the pattern of information-logisticsfinancial flows.

\subsection{Business Ecosystem and Business Model Innovation}

To determine the appropriate business model, an innovating firm bundles innovation and product together and assumes the responsibility for the entire value chain, including design, manufacturing, and distribution [51]. Companies can also innovate in business models and find ways to change different sides of the market to make money from their platform or from complements and different kinds of transactions or advertising [70]. In essence, the evolution of business ecosystems is the change in the partner structure. The evolution occurs by involving new partners and changing the roles of existing partners, potentially also involving a change in these cross-border e-commerce companies' positions within the business ecosystem.

The five core businesses result in the participation of various stakeholders in the business ecosystem and it might change their positions within the business ecosystem. For instance, logistics companies were extended companies in the export and import business model, while in the freight forwarding business model, they are direct suppliers. On the other hand, financial institutions play a loose role in the early stage, whilst they recently became critical to provide supply chain finance services.

During the business model innovation stages, Zongteng shifted its role from e-tailer to an integrated information, logistics, and financial service provider. The business model enables Zongteng to share the value with the participators. Zongteng became the keystone player in the ecosystem [53] that develops a platform, brings value to its ecosystem partners, and creates more value as a whole. Thus, we propose that

P2a: SCI leads to a change of supply chain structure and hence the business ecosystem.

P2b: The roles of ecosystem partners' change along with the business model innovation stage (e.g., logistics partners and finance institutions).

P2c: A cross-broader e-commerce company tends to become the keystone player in the business ecosystem to expand it with more partners and create more value.

\section{Conclusions}

This study attempts to answer the research question of how SCI contributes to business model innovation in cross-border e-commerce. We examined the changing business models of a Chinese cross-border e-commerce company that continuously innovates its supply chain and corresponding business models and improves its business ecosystem to answer this question. We adopted the Business Model Canvas to define the nine building blocks (customer segments, value proposition, channels, customer relationships, revenue streams, key resources, key activities, key partnerships, 
and cost structure) of the company's five core business (export, import, freight forwarding, overseas warehousing, and bonded warehousing). We advanced two sets of propositions (6 in total) in the paper.

This study has several contributions. First, it contributes to the SCI literature. Traditionally, logistics strategy and innovation are considered as supportive activities in the value chain [71], but now SCM is the key to a firm's competitive advantage [30,31]. In terms of content, we identified several interesting themes. Specifically, four main areas in B2C e-commerce logistics operations have an environmental impact: transportation planning and management, warehousing, packaging, and distribution network design [31]. We found that overseas warehouses, bonded warehouses, and supply chain finance present capabilities as part of a core business model in cross-border e-commerce. Supply chain and logistics present a fertile ground for business model innovation in the cross-border e-commerce context. Second, in terms of both the business ecosystem life cycle and business model canvas, we enrich the business ecosystem literature in the cross-border e-commerce context, illustrating the evolution of the business ecosystem by a vivid example. Third, it contributes to the discussion of the management of three flows in supply chain management that a cross-border e-commerce company's SCI follows the pattern of information-logistics-financial flows.

The study also has some practical implications for cross-border e-commerce companies. First, the analysis of the evolution stage and business models based on the nine components of the business model canvas provides managers with a roadmap to position their own companies. Second, this framework helps policymakers understand how the cross-border e-commerce business ecosystem evolves and the kinds of resources required during the process and thereby allow them to design policies accordingly. Third, our case company also provides a best practice reference to other cross-border e-commerce companies. Its SCI experience may not only be relevant to Chinese companies but also to companies in other developing countries.

This study also has some limitations. First, it is a single case study which may not have universal applicability. Future studies may examine multiple cases to generate a more instructive meaning. Second, since the cross-border e-commerce environment is characterised by uncertainty, the business model or the business ecosystem may not develop as predicted for other companies and in other contexts.

Author Contributions: Y.W. and F.J. contributed to establishment and application of the framework. T.S. and Y.G. advised in the process of paper writing and revised the whole paper. Y.W. performed the data collection. All authors contributed to the writing, and have read and approved the final manuscript.

Funding: This research was funded by National Social Science Foundation Project, grant number 15CJY010.

Conflicts of Interest: The authors declare no conflict of interest.

\section{References}

1. World Trade Organization. E-Commerce in Developing Countries: Opportunities and Challenges for Small and Medium-Sized Enterprises; World Trade Organization (WTO): Geneva, Switzerland, 2013; p. 1.

2. $\mathrm{Li}, \mathrm{S}$.; $\mathrm{Wu}, \mathrm{Y}$. Development Strategy of Cross-border E-commerce in China. DEStech Transactions on Social Science, Education and Human Science. In Proceedings of the MSIE Conference, Jinan, China, 14-15 October 2017; pp. 826-830.

3. Kawa, A.; Zdrenka, W. Conception of integrator in cross-border e-commerce. Logforum 2016, 12, 63-73. [CrossRef]

4. Swaine, M.D. Chinese views and commentary on the 'One Belt, One Road' initiative. China Leadersh. Monit. $2015,47,3$.

5. Tsui, S.; Wong, E.; Chi, L.; Tiejun, W. One Belt, One Road. Monthly Review, 1 January 2017.

6. Hongfei, Y. National Report on E-Commerce Development in China; Inclusive and Sustainable Industrial Development Working Paper Series WP17; United Nations Industrial Development Organization: Vienna, Austria, 2017.

7. JD Big Data Research Institute. 'One Belt, One Road' Cross-Border E-Commerce Consumption Trend Report; JD Big Data Research Institute: Beijing, China, 2017. 
8. Ghiasy, R.; Zhou, J. The Silk Road Economic Belt: Considering Security Implications and EU-China Cooperation Prospects; Stockholm International Peace Research Institute: Solna, Sweden, 2017; p. 59.

9. Huang, Y. Understanding China's Belt \& Road initiative: Motivation, framework and assessment. China Econ. Rev. 2016, 40, 314-321.

10. Huaxia. Cross-Border E-Commerce to Boost Chinese Foreign Trade. Available online: http://news. xinhuanet.com/english/2016-01/07/c_134987430.htm (accessed on 7 January 2016).

11. iiMedia Research. 2017-2018 China Cross-border E-commerce Market Research Report. Available online: http:/ / www.iimedia.cn/60608.html (accessed on 6 February 2018).

12. iResearch. E-2018 China's Cross-Border Import Retail Commerce Report. Available online: http:/ / www. iresearchchina.com/content/details8_46058.html (accessed on 25 July 2018).

13. Liu, X.; Chen, D.; Cai, J. The Operation of the Cross-Border e-commerce Logistics in China. Int. J. Intell. Inf. Syst. 2015, 4, 15-18.

14. Zhang, Y.B. The new ecosystem of cross-border e-commerce between eu and china based on blockchain. China Bus. Mark. 2018, 32, 66-72.

15. Tansley, A.G. The use and abuse of vegetational concepts and terms. Ecology 1935, 16, 284-307. [CrossRef]

16. Moore, J.F. Predators and prey: A new ecology of competition. Harv. Bus. Rev. 1993, 71, 75-83. [PubMed]

17. Mahadevan, B. Business models for Internet-based e-commerce: An anatomy. Calif. Manag. Rev. 2000, 42, 55-69. [CrossRef]

18. Abdelkafi, N.; Pero, M. Supply chain innovation-driven business models: Exploratory analysis and implications for management. Bus. Process. Manag. J. 2018, 24, 589-608. [CrossRef]

19. Arlbjørn, J.S.; Haas, H.D.; Munksgaard, K.B. Exploring supply chain innovation. Logist. Res. 2011, 3, 3-18. [CrossRef]

20. Chesbrough, H.; Rosenbloom, R.S. The role of the business model in capturing value from innovation: Evidence from xerox corporation's technology spin-off companies. Soc. Sci. Electron. Publ. 2002, 11, 529-555. [CrossRef]

21. Benner, M.J.; Tushman, M.L. Exploitation, exploration, and process management: The productivity dilemma revisited. Acad. Manag. Rev. 2003, 28, 238-256. [CrossRef]

22. Lee, V.-H.; Ooi, K.-B.; Chong, A.Y.-L.; Sohal, A. The effects of supply chain management on technological innovation: The mediating role of guanxi. Int. J. Prod. Econ. 2018, 205, 15-29. [CrossRef]

23. Gligor, D.M.; Holcomb, M.C. Antecedents and Consequences of Integrating Logistics Capabilities across the Supply Chain. Transp. J. 2014, 53, 211-234. [CrossRef]

24. Dobrovnik, M.; Herold, D.; Fürst, E.; Kummer, S. Blockchain for and in Logistics: What to Adopt and Where to Start. Logistics 2018, 2, 18. [CrossRef]

25. Contractor, F.J. Is International Business Good for Companies? The Evolutionary or Multistage Theory of Internationalization vs. the Transaction Cost Perspective. Manag. Int. Rev. 2007, 47, 453-475. [CrossRef]

26. Marucheck, A.; Greis, N.; Mena, C.; Cai, L. Product safety and security in the global supply chain: Issues, challenges and research opportunities. J. Oper. Manag. 2011, 29, 707-720. [CrossRef]

27. Carter, J.R.; Pearson, J.N.; Li, P. Logistics barriers to international operations: The case of the People's Republic of China. J. Bus. Logist. 1997, 18, 129.

28. Żurek, J. E-Commerce Influence on Changes in Logistics Processes. Logforum 2015, 11, 129-138. [CrossRef]

29. Nica, E. Environmentally Sustainable Transport and E-Commerce Logistics. Econ. Manag. Financ. Mark. 2015, 10, 86-92.

30. Yang, Q.; Zhao, X.; Yeung, H.J.; Liu, Y. Improving logistics outsourcing performance through transactional and relational mechanisms under transaction uncertainties: Evidence from China. Int. J. Prod. Econ. 2016, 175, 12-23. [CrossRef]

31. Mangiaracina, R.; Marchet, G.; Perotti, S.; Tumino, A. A review of the environmental implications of B2C e-commerce: A logistics perspective. Int. J. Phys. Distrib. Logist. Manag. 2015, 45, 565-591. [CrossRef]

32. Timmers, P. Business models for electronic markets. Electron. Mark. 1998, 8, 3-8. [CrossRef]

33. Gambardella, A.; McGahan, A.M. Business model innovation: General purpose technologies and their implications for industry structure. Long Range Plan. 2010, 43, 262-271. [CrossRef]

34. Stewart, D.W.; Zhao, Q. Internet marketing, business models, and public policy. J. Public Policy Mark. 2000, 19, 287-296. [CrossRef] 
35. Rappa, M.A. The utility business model and the future of computing services. IBM Syst. J. 2004, 43, 32-42. [CrossRef]

36. Hawkins, R. The phantom of the marketplace: Searching for new e-commerce business models. Euro CPR 2002, 46, 297-329.

37. Applegate, L.M. Emerging E-Business Models: Lessons from the Field; HBS No. 9-801-172; Harvard Business School: Boston, MA, USA, 2001.

38. Osterwalder, A.; Pigneur, Y.; Lagha, S.B. Modeling e-business with eBML. Ind. Organ. 2002, 3, 75.

39. Osterwalder, A.; Pigneur, Y. Business Model Generation: A Handbook for Visionaries, Game Changers, and Challengers; John Wiley and Sons: New Jersey, NJ, USA, 2010.

40. Johnson, M.W.; Christensen, C.M.; Kagermann, H. Reinventing your business model. Harv. Bus. Rev. 2008, $86,57-68$.

41. Björkdahl, J.; Holmén, M. Editorial: Business model innovation-the challenges ahead. Int. J. Prod. Dev. 2013, 18, 213-225.

42. Demil, B.; Lecocq, X. Business Model Evolution: In Search of Dynamic Consistency. Long Range Plan. 2010, 43, 227-246. [CrossRef]

43. Amit, R.; Zott, C. Creating Value through Business Model Innovation. MIT Sloan Manag. Rev. 2012, 53, 41-49.

44. Pohle, G.; Chapman, M. IBM's global CEO report 2006: Business model innovation matters. Strategy Leadersh. 2006, 34, 34-40. [CrossRef]

45. Bouncken, R.B.; Fredrich, V. Business model innovation in alliances: Successful configurations. J. Bus. Res. 2016, 69, 3584-3590. [CrossRef]

46. Mitchell, D.; Coles, C. The ultimate competitive advantage of continuing business model innovation. J. Bus. Strategy 2003, 24, 15-21. [CrossRef]

47. Chesbrough, H. Business model innovation: Opportunities and barriers. Long Range Plan. 2010, 43, 354-363. [CrossRef]

48. Zott, C.; Amit, R.; Massa, L. The business model: Recent developments and future research. J. Manag. 2011, 37, 1019-1042.

49. Amit, R.; Zott, C. Value creation in e-business. Strat. Manag. J. 2001, 22, 493-520. [CrossRef]

50. George, G.; Bock, A.J. The business model in practice and its implications for entrepreneurship research. Entrep. Theory Pract. 2011, 35, 83-111. [CrossRef]

51. Teece, D.J. Business models, business strategy and innovation. Long Range Plan. 2010, 43, 172-194. [CrossRef]

52. Moore, J.F. The Death of Competition: Leadership and Strategy in the Age of Business Ecosystems; HarperCollins Publishers: New York, NY, USA, 1996.

53. Iansiti, M.; Levien, R. Strategy as ecology. Harv. Bus. Rev. 2004, 82, 68-81. [PubMed]

54. Hartigh, E.D.; Asseldonk, T.V. Business ecosystems: A research framework for investigating the relation between network structure, firm strategy, and the pattern of innovation diffusion. In Proceedings of the ECCON 2004 Annual Meeting, Driebergen, The Netherlands, 22-23 October 2004.

55. Iyer, B.; Lee, C.H.; Venkatraman, N. Managing in a "small world ecosystem": Lessons from the software sector. Calif. Manag. Rev. 2006, 48, 28-47. [CrossRef]

56. Rong, K. Nurturing Business Ecosystem from Firm Perspectives: Lifecycle, Nurturing Process, Constructs, Configuration Pattern. Ph.D. Thesis, University of Cambridge, Cambridge, UK, 2011. Unpublished.

57. Mitleton-Kelly, E. Complex Systems and Evolutionary Perspectives on Organisations: The Application of Complexity Theory to Organisations; Ten Principles of Complexity and Enabling Infrastructures; Elsevier Science Ltd.: Oxford, UK, 2003; pp. 23-52.

58. MacCarthy, B.L.; Blome, C.; Olhager, J.; Srai, J.S.; Zhao, X. Supply chain evolution-theory, concepts and science. Int. J. Oper. Prod. Manag. 2016, 36, 1696-1718. [CrossRef]

59. Yin, R. Case Study Research; Sage Publications: Los Angeles, CA, USA, 2009.

60. Stuart, I.; McCutcheon, D.; Handfield, R.; McLachlin, R.; Samson, D. Effective case research in operations management: A process perspective. J. Oper. Manag. 2002, 20, 419-433. [CrossRef]

61. Ketokivi, M.; Choi, T. Renaissance of case research as a scientific method. J. Oper. Manag. 2014, 32, $232-240$. [CrossRef]

62. Ardito, L.; Ferraris, A.; Messeni Petruzzelli, A.; Bresciani, S.; Del Giudice, M. The role of universities in the knowledge management of smart city projects. Technol. Forecast. Soc. Chang. Forthcom. 2018. [CrossRef] 
63. D'Ippolito, B.; Miozzo, M.; Consoli, D. Knowledge systematisation, reconfiguration and the organisation of firms and industry: The case of design. Res. Policy 2014, 43, 1334-1352. [CrossRef]

64. Eisenhardt, K.M. Building theories from case study research. Acad. Manag. Rev. 1989, 14, 532-550. [CrossRef]

65. Miles, M.; Huberman, M. Focusing and Bounding the Collection of Data: The Substantive Start an Expanded Source Book: Qualitative Data Analysis; SAGE: London, UK, 1994; pp. 16-39.

66. Lau, K.H.; Zhang, J. Drivers and obstacles of outsourcing practices in China. Int. J. Phys. Distrib. Logist. Manag. 2006, 36, 776-792.

67. Pang, Y. Research on International Logistics Operation Mode under the Environment of Cross-border E-business. China Bus. Mark. 2015, 10, 15-20.

68. Zhang, B.; Zhou, P.; Meng, L. Study on the Integration of Cross-border E-commerce and Logistics Development. Logist. Sci-Tech 2014, 10, 54-58.

69. Rai, A.; Patnayakuni, R.; Seth, N. Firm performance impacts of digitally enabled supply chain integration capabilities. Manag. Inf. Syst. Q. 2006, 30, 225-246. [CrossRef]

70. Eisenmann, T.R. Platform-Mediated Networks: Definitions and Core Concepts; Harvard Business School Module Note 807-049; Harvard Business School: Boston, MA, USA, 2006.

71. Porter, M.E. Competitive Advantage: Creating and Sustaining Superior Performance; FreePress: New York, NY, USA, 1985.

(C) 2018 by the authors. Licensee MDPI, Basel, Switzerland. This article is an open access article distributed under the terms and conditions of the Creative Commons Attribution (CC BY) license (http:/ / creativecommons.org/licenses/by/4.0/). 